\title{
INTRODUCTION: LITERARY AND CULTURAL INTERSECTIONS
}

\author{
Shalini Nadaswaran Carol Elizabeth Leon Nicholas O. Pagan
}

This special issue of SARE demonstrates how the journal has always both remained true to its roots in Southeast Asian literature (in English) and in Commonwealth and Third World Literature (later redefined as "Postcolonial" Literature) while also embracing the ever-fertile field of cultural studies. The editors of SARE have long been aware of the ability of cultural studies to provide compelling theories - including feminist and postcolonial - to help ensure that whether we turn to so-called "high" literature or to less canonical writing we should never lose sight of the inexorable bond between text and culture. This symbiosis was captured in the theme of a colloquium staged by the Department of English at the University of Malaya in December, 2013: "Literary and Cultural Intersections." Several of the articles in this issue were initially presented as papers during that colloquium. The best papers were later accepted for publication along with other peer-reviewed papers. This issue also clearly exemplifies SARE's commitment to publishing the work of promising, fledgling researchers alongside that of more experienced scholars.

The first essay in this collection begins on an upbeat note. "The most vibrant intersection of literature and culture, and literature's most resolute function," writes Bill Ashcroft, "may well lie in the generation of hope". A colossus in the field of postcolonial studies, Ashcroft has always had a keen eye on the transformations taking place within postcolonialism as it interacts with other theoretical approaches and always looks toward the future. It is especially in African literature that Ashcroft finds portrayals of societies in which indigenous people are able to tap into an innate spirit of hope and counter attempts by the colonizer to define and restrict them. Ashcroft's optimism concerning such postcolonial societies stands in distinct contrast to other societies, many of those, for instance, involved in the Arab Spring where the efforts to incorporate West-leaning versions of democracy seem doomed to perennial failure.

The African thread and the problematic term "democracy" finds its way into Mustapha Bala Ruma's essay on Ngugi wa Thiong'o's Wizard of the Crow which presents a picture of a free republic where megalomania rules and people can only make a mockery of the very idea of democracy. This fictional world seems completely cut off from Ashcroft's vision of hope which does, however, make a welcome return in Leonard Jeyam's essay on the Malaysian writers Wong Phui Nam and K.S. Maniam. Noting the writers' postcolonial concerns, Jeyam finds hope in some of Maniam's fictional landscapes which are "filled with energy and color" and, more importantly, in some of Maniam's characters who search for and retain a belief in a spiritual reality, either vaguely connected to the land or to "the older religions of South East Asia."

Malaysian subject matter is also very prominent in the essays by Sharifah Aishah Osman, David Tneh Cheng Eng, and Gladys Koh. Osman considers the writings of two $19^{\text {th }}$ century British women writers who wrote about Asian countries, especially Malaya, and who strongly countered the patriarchal tendencies of colonial discourse. Tneh uses the plays of Kee Thuan Chye to draw attention to some of the political struggles based on the striking inequalities that 
persist in Malaysian society. Koh examines Malaysian and Singaporean food blogs in relation to identity formation, particularly of young people. Koh's essay moves far away from the traditional English Department paradigm which involves the study of canonical literary texts and takes up a bold position on the cultural side of the literature-culture nexus in the twenty first century.

Walter Perera and Haleh Zargarzadeh revisit the postcolonial setting. Perera considers literature set in Sri Lanka by authors who once lived in Sri Lanka but whose fiction reflects a lack of understanding of indigent people and especially misconceptions concerning interactions between the Sri Lankan rich and poor. Zargarzadeh's essay on Derek Walcott's The Odysseydraws attention to the wounds suffered not just by Caliban but also by Prospero. Zargarzadeh sees Walcott as drawing attention to the idea that although the pain felt by the colonizer invariably pales in comparison with that felt by the colonized, the pain felt by the colonizer should not be forgotten.

Foong Soon Sen's essay on Paolo Coelho's Brida encroaches on the spiritual domain mentioned earlier in the collection. The Brazillian writer Coelho, however, treats the spiritual in far more detail than his Malaysian counterpart Maniam and shows how the spiritual is at the same time both a function of people's connectedness to each other and of their relationship to the sacred.

Finally, two essays written by European scholars based in Malaysia are included in this edition. Both focus on inter-cultural concerns. Loes Nas analyzes American writer Dave Eggers's What is the What: The Autobiography of Valentino Achak Deng: A Novel, the story of man who escapes state-sponsored violence against various tribes in his own country only to become a victim in the U.S. beaten up, gagged, and robbed by African-American bigoted thugs. Nas describes Ding who is at home and at peace nowhere as taking on what cultural theorist Paul Gilroy labels "infrahumanity."

Nicholas O. Pagan addresses attitudes towards garbage, placing treatments of garbagephilosophical, psychological, spiritual--in novels by North American writers Margaret Lawrence and Don De Lillo alongside Vietnamese writer The Phong's working on the same theme in his short story "The Rubbish Tip Outside the City." Pagan ends by observing that despite the universally generally negative connotations of the word "garbage," Phong's work in particular draws attention to the idea that garbage can actually bring out the best in the human spirit.

This collection of essays displays the complexities and richness that reside in the intersections between literature and culture and demonstrate the various approaches in theorizing these exciting connections. 